\title{
Metal Contamination in Macrobrachium rosenbergii from Sarawak River, Malaysia and its Health Risk to Human
}

\author{
F. A. Idrus $\dagger$, M. M. Basri, K. A. A. Rahim and A. C. Lee
}

Faculty of Resource Science and Technology, Universiti Malaysia Sarawak, 94300 Kota Samarahan, Sarawak, Malaysia $\dagger$ Corresponding author: F. A. Idrus; aifarah@unimas.my

Nat. Env. \& Poll. Tech. Website: www.neptjournal.com

Received: 02-06-2020

Revised: 03-09-2020

Accepted: 16-09-2020

\section{Key Words:}

Heavy metals

Macrobrachium rosenbergii

Human health risk

Sarawak river

\begin{abstract}
An assessment of heavy metal concentration in wild-captured Macrobrachium rosenbergii (giant freshwater prawns) from their natural habitat is important since it is susceptible to environmental pollution due to the rapid development and human activities along the Sarawak River. This study aimed to estimate the heavy metal contamination in muscles, exoskeletons and gills of the $M$. rosenbergii and to estimate the health risk assessment to human consumption. The concentration of heavy metals was analyzed by the flame atomic absorption spectrophotometer and the flow injection mercury system. The metal concentrations in prawns were detected in the following order: $\mathrm{Hg}<\mathrm{Cd}<\mathrm{Co}<\mathrm{Cu}<\mathrm{Zn}$; in all body parts $(P<0.05)$, where a high concentration of metals was recorded in gills due to its function as the excretion site of contaminants from the body. A positive correlation of $\mathrm{Co}$, $\mathrm{Cu}$, and $\mathrm{Zn}$ in muscles and gills was observed with the increasing size of prawns. The human health risk assessment indicated a less potential adverse health effect of prawns for consumption from Sarawak River (hazard index values < 1). All samples contained metals below the Joint FAO/WHO Expert Committee on Food Additives (JECFA) permissible limit for human consumption (Cd < $2 \mathrm{mg} / \mathrm{kg}$; Cu $<30 \mathrm{mg} / \mathrm{kg}$; $\mathrm{Zn}<$ $150 \mathrm{mg} / \mathrm{kg} ; \mathrm{Hg}<1 \mathrm{mg} / \mathrm{kg}$ ). Therefore, M. rosenbergii from the Sarawak River were not contaminated enough to prevail high risk on human health, but regular monitoring is suggested for seasonal variability of heavy metals in M. rosenbergii for safeguarding human health.
\end{abstract}

\section{INTRODUCTION}

Heavy metal contamination has got serious attention worldwide due to the increase in agricultural, industrial and fisheries activities, domestic wastes and technological usage (Aytekin et al. 2019, Mostafiz et al. 2020). The fastgrowing population in Kuching (the capital city of Sarawak, Malaysia) has seen the increasing water demand, resulting in poorly treated effluents, the main generator of the 'black and grey waters' flowing into the Sarawak River. The 'black water' refers to wastewater from septic tanks and 'grey water' is the water discharge from kitchens, bathrooms and washing areas (Natural Resources and Environmental Board Sarawak 2017). Both 'black and grey waters' effluents may contribute heavy metals to the environment (Eriksson et al. 2010). Moreover, water quality in the Sarawak River was classified as Class III with a low concentration of heavy metals (Natural Resources and Environmental Board 2001). However, the concentration of heavy metals such as mercury $(\mathrm{Hg})$, cadmium $(\mathrm{Cd})$, lead $(\mathrm{Pb})$ and zinc $(\mathrm{Zn})$ was found considerably high in sediment, which was potentially toxic to sensitive organisms (Natural Resources and Environmental Board 2001).
Heavy metals from the effluents can stay for a long time in aquatic environments, such as rivers, then can contaminate aquatic organisms and enter the food chain, subsequently creating significant health risks and economic costs for residents (Yunus 2020, Aytekin et al. 2019). As heavy metals are non-biodegradable, they can accumulate in water and sediment, and can be transferred to living organisms such as fish and crustaceans (Mostafiz et al. 2020), through bioaccumulation and biomagnification. Fish and crustaceans that stay at the higher trophic levels of the food chains are considered to be one of the important groups for transferring heavy metals to humans. The prolonged consumption of heavy metals may lead to severe effect on living organisms. $\mathrm{Hg}$ is known as a deadly and accumulative poison even when consumed in small quantities, and capable of deadening nerve receptor in humans, thus considered as a public health problem. $\mathrm{Cd}$ is a highly toxic metal and accumulates primarily in liver and kidney of mammals through the food chain. Exposure of cobalt (Co) to Macrobrachium rosenbergii may reduce the female fecundity (Stalin et al. 2019). Although Copper $(\mathrm{Cu})$ involves in the prawns' oxygen-carrying pigment haemocyanin, it may also cause poisoning to humans. Poisoning by $\mathrm{Cu}$ and $\mathrm{Zn}$ may cause 
gastrointestinal disorders, diarrhoea, stomatitis, tremor, depression, vomiting and ataxia (Anani \& Olomukoro 2018). The development of the waterfront in Sarawak River may give negative impacts on the aquatic organisms such as $M$. rosenbergii or locally known as giant freshwater prawn. $M$. rosenbergii were commonly served as regional and local fisheries importance, and economic values since they meet the high demand of protein source and have high domestic and export potential (Banu \& Christianus 2016). This species is abundant in Sarawak River and can be wild-captured by local fishermen. However, rapid urbanization along the Sarawak River may increase the contamination of heavy metals in the water and sediment. Moreover, there is still no study on the heavy metal contamination in the wild $M$. rosenbergii particularly in Sarawak River. Contamination of this type of prawn with heavy metals may give a potential risk to human health. Therefore, this study sought to (1) quantify the contamination level of heavy metals $(\mathrm{Cd}, \mathrm{Co}$, $\mathrm{Cu}, \mathrm{Zn}, \mathrm{Hg}$ ) in $M$. rosenbergii from the Sarawak River, and (2) calculate the health risk assessment to humans upon consumption of contaminated prawns.

\section{MATERIALS AND METHODS}

M. rosenbergii were captured using the fishing rod from the Sarawak River on $12^{\text {th }}$ October 2016 at the longitude $01^{\circ} 33^{\prime} 40.3^{\prime \prime} \mathrm{N}$ and latitude $110^{\circ} 20^{\prime} 34.0^{\prime \prime} \mathrm{E}$ (Fig. 1). Surface sediment samples were collected by the plastic corer. All samples were then stored in the zipper polyethylene bags, labelled properly and placed in the cooler box with ice during the transportation to the Aquatic Chemistry Laboratory. The total wet weight and the total length of the individual prawn were recorded before the dissection (Table 1). In the laboratory, prawn and sediment samples were kept at $-20^{\circ} \mathrm{C}$ in a
Table 1: Total length and total weight of M. rosenbergii samples $(\mathrm{n}=21)$.

\begin{tabular}{|lllll|}
\hline Sex & $\mathrm{n}$ & $\begin{array}{l}\text { Reproductive } \\
\text { state }\end{array}$ & $\begin{array}{l}\text { Total length } \\
(\mathrm{cm})\end{array}$ & Total weight $(\mathrm{g})$ \\
\hline Female & 13 & Mature & $14.32 \pm 1.86$ & $26.11 \pm 9.10$ \\
Male & 8 & Mature & $17.45 \pm 2.81$ & $59.55 \pm 3.50$ \\
\hline
\end{tabular}

There were significant differences between female and male prawns $(\mathrm{p}<$ $0.05)$ total length and total weight.

freezer. The mature male and female $M$. rosenbergii can be identified by observing their second pleopod, as explained in detail in Idrus et al. (2018).

The dissected muscle, exoskeleton, and gill were weighed and dried in the oven at $60^{\circ} \mathrm{C}$ until it achieved a constant weight to ensure it was completely dry. About $80 \%$ weight differences were recorded between wet and dried samples, due to moisture loss during the drying process. Before the digestion process, dried samples were ground to powder form using the mortar and pestle. The digestion process was done by heating $0.2 \mathrm{~g}$ of the sample in $5 \mathrm{~mL}$ of concentrated $\mathrm{HNO}_{3}$ (Tu et al. 2008) on the hot plate until the solution turns clear (Idrus et al. 2018). Sediment samples were air-dried and ground before digestion using the aqua regia method as in Hseu et al. (2002) by heating on a hot plate. All samples, including the standard solutions, were pre-concentrated by using the multielements pre-concentration step by solid phase extraction using iminodiacetate chelating resin (Toyopearl AF Chelate-650M) method as described in Idrus et al. (2018), before analyzing the heavy metal concentrations. $\mathrm{Cd}, \mathrm{Co}$, $\mathrm{Cu}$ and $\mathrm{Zn}$ were analyzed by Flame Atomic Absorption Spectrophotometer (FAAS; Thermo Scientific iCE 3500), and $\mathrm{Hg}$ by the Flow Injection Mercury System (FIMS; Perkin Elmer-FIMS 400). All readings were determined in three replicates. The standard calibration of each metal was

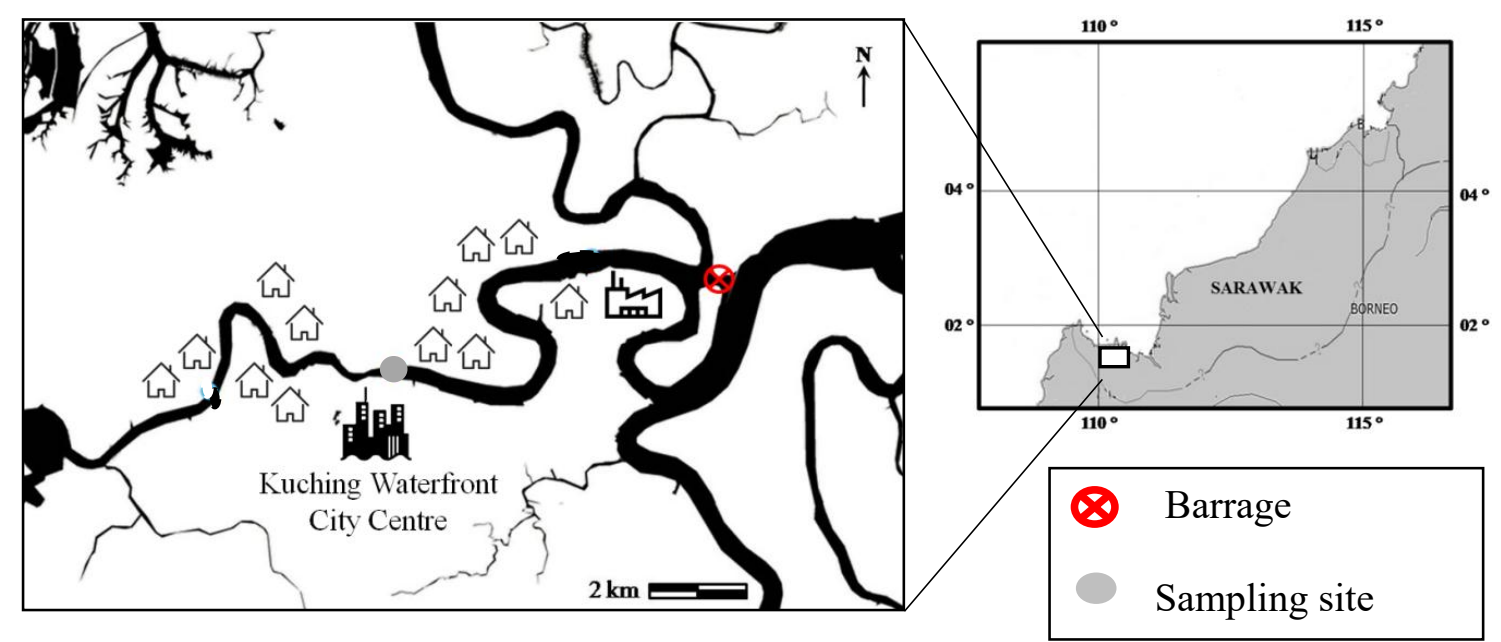

Fig. 1: Sampling site for M. rosenbergii in Sarawak River. 
Table 2: Feedback from the respondents ( $n=100$; male: 46 persons, female 54 persons) from the survey of daily consumption of $M$. rosenbergii by the residents nearby the Sarawak River

\begin{tabular}{|llll|}
\hline Parameters & Minimum & Maximum & Average \\
\hline Age (years old) & 21 & 67 & \\
Body weight $(\mathrm{kg})$ & 39 & 90 & 60 \\
$\begin{array}{l}\text { Estimation of weight of prawns } \\
\text { intake daily (g/day) }\end{array}$ & 50 & 300 & 150 \\
\hline
\end{tabular}

performed with $\mathrm{r}^{2}$ between 0.9937 and 0.9996. In this study, the certified reference materials (CRMs) from the National Research Council Canada of LUTS-1 (non-defatted lobster hepatopancreas) were used for M. rosenbergii samples and MASS-4 was used for sediment samples. CRMs analyses were followed the same methods as for prawn and sediment samples.

The survey of daily consumption of $M$. rosenbergii was done by questionnaire to the local residents $(\mathrm{n}=100)$ that live close to Sarawak River. The summary of the survey is given in Table 2. All respondents got the prawns from the Sarawak River, either by catching themselves or bought from other fishermen who caught them from the Sarawak River.

The daily intake of metal (DIM) was calculated to estimate the average daily metal accumulation in a consumer for specified bodyweight, without taking into account the possible metabolic excretion of the metal. The DIM was calculated based on Equation (1) given by Islam et al. (2017).

$\mathrm{DIM}=\frac{\mathrm{K}_{\text {conversion factor }} \times \mathrm{C}_{\text {metal }} \times \mathrm{D}_{\text {average prawn intake }}}{\mathrm{B}_{\text {average body weight }}} \ldots$ (1)

where $\mathrm{K}_{\text {conversion factor }}=$ Conversion factor of 0.1455 was used based on the moisture content of the samples (Islam et al. 2017); $C_{\text {metal }}=$ Metal concentration in prawns $(\mu \mathrm{g} / \mathrm{g}) ; \mathrm{D}_{\text {average prawn intake }}=$ Average daily intake of prawns by the local residents around Sarawak River (150 g/day, $\mathrm{B}_{\text {average body weight }}=$ Average body weight $(60 \mathrm{~kg}$, (Table 2$)$. This intake figure includes all modes of prawn meals.

The health risk index (HRI) was calculated using the Equation (2) as in Cui et al. (2004).

$$
\mathrm{HRI}=\frac{\mathrm{DIM}}{\mathrm{RfD}}
$$

where DIM = Daily intake of metal $(\mu \mathrm{g} / \mathrm{kg} /$ day $) ; \mathrm{RfD}=$ Oral reference dose established by USEPA. If the HRI value is larger than 1 for any metal in food from oral consumption, it means that the consumer population was at a potential health risk. The calculation of HRI was depended on the DIM value and the oral reference dose established by USEPA (1994, 2001), where the RfD values for Cd was $0.83 \mu \mathrm{g} / \mathrm{kg} / \mathrm{day}$, $\mathrm{Cu}$ was $500 \mu \mathrm{g} / \mathrm{kg} / \mathrm{day}$, Zn was $1000 \mu \mathrm{g} / \mathrm{kg} /$ day and $\mathrm{Hg}$ was $0.10 \mu \mathrm{g} / \mathrm{kg} / \mathrm{day}$. For Co, there was no established reference value given by USEPA, therefore an RfD value of $30 \mu \mathrm{g} /$ $\mathrm{kg}$ /day for Co (Finley et al. 2012) was used in this study.

The hazard index (HI) was used to estimate the potential human health risks upon consuming more than one metal, where the HI is the sum of the HRI derived from the prawns, as shown in Equation (3):

$\mathrm{HI}=\Sigma \mathrm{HRI}=\mathrm{HRI}_{\mathrm{Cd}}+\mathrm{HRI}_{\mathrm{Co}}+\mathrm{HRI}_{\mathrm{Cu}}+\mathrm{HRI}_{\mathrm{Zn}}+\mathrm{HRI}_{\mathrm{Hg}}$

where $\mathrm{HRI}_{\mathrm{Cd}}, \mathrm{HRI}_{\mathrm{Co}}, \mathrm{HRI}_{\mathrm{Cu}}, \mathrm{HRI}_{\mathrm{Zn}}, \mathrm{HRI}_{\mathrm{Hg}}$ are the health risk indexes as calculated in Equation (2) or also known as hazard quotients for $\mathrm{Cd}, \mathrm{Co}, \mathrm{Cu}, \mathrm{Zn}$, and $\mathrm{Hg}$, respectively. It is assumed that the $\mathrm{HI}$ value larger than 1 will give adverse effects on human health due to the multiple metal exposures.

All metal concentrations data were expressed in $\mathrm{mg} / \mathrm{kg}$ of the flesh weight (wet weight) \pm standard deviation $(\mathrm{mg} /$ $\mathrm{kg} \mathrm{FW}$ ). The variations between metals content in different body parts of the prawns and their size and gender were tested by two-way ANOVA, while variations of total length and total weight were tested by $t$-test. The Pearson's Correlation and linear regressions were used to compare the correlation of metals in muscle, exoskeleton and gill of $M$. rosenbergii. In all cases, the level of significance was set at $\square=0.05$. The statistical analyes were performed by using SPSS for Windows Version 22.

\section{RESULTS AND DISCUSSION}

The obtained values and metals recovery of $\mathrm{Cd}, \mathrm{Co}, \mathrm{Cu}, \mathrm{Zn}$ and $\mathrm{Hg}$ are given in Table 3, which suggest the efficiency of the chelation methods used.

The allometric length-weight relationship of the $M$. rosenbergi was done using the Equation 4 as provided by Rocha et al. (2015):

Table 3: The heavy metals recovery of $\mathrm{Cd}, \mathrm{Co}, \mathrm{Cu}, \mathrm{Zn}$ and $\mathrm{Hg}$ in LUTS-1 and MASS- 4 .

\begin{tabular}{|lllll|}
\hline CRM & Metals & $\begin{array}{l}\text { Certified } \\
\text { value }\end{array}$ & $\begin{array}{l}\text { Obtained } \\
\text { value }\end{array}$ & $\begin{array}{l}\text { Recovery } \\
(\%)\end{array}$ \\
\hline $\begin{array}{l}\text { LUTS-1 } \\
(\mathrm{mg} / \mathrm{kg})\end{array}$ & $\mathrm{Cd}$ & $14.2 \pm 1.0$ & $12.9 \pm 0.6$ & $91 \pm 4$ \\
& $\mathrm{Co}$ & $0.34 \pm 0.04$ & $0.37 \pm 0.06$ & $109 \pm 4$ \\
& $\mathrm{Cu}$ & $107 \pm 8$ & $116 \pm 11$ & $108 \pm 7$ \\
& $\mathrm{Zn}$ & $82.9 \pm 2.2$ & $86.4 \pm 3.5$ & $104 \pm 5$ \\
& $\mathrm{Hg}(\mu \mathrm{g} / \mathrm{kg})$ & $16.7 \pm 2.2$ & $14.1 \pm 1.5$ & $84 \pm 6$ \\
$\mathrm{MASS}-4$ & $\mathrm{Cd}$ & $0.28 \pm 0.04$ & $0.31 \pm 0.03$ & $110 \pm 2$ \\
$(\mathrm{mg} / \mathrm{kg})$ & $\mathrm{Co}$ & $13.0 \pm 0.8$ & $11.8 \pm 1.3$ & $91 \pm 6$ \\
& $\mathrm{Cu}$ & $32.9 \pm 1.8$ & $35.1 \pm 1.2$ & $106 \pm 3$ \\
& $\mathrm{Zn}$ & $147 \pm 6$ & $155 \pm 9$ & $105 \pm 5$ \\
& $\mathrm{Hg}$ & $0.09 \pm 0.04$ & $0.07 \pm 0.02$ & $107 \pm 6$ \\
\hline
\end{tabular}




$$
\mathrm{W}=\mathrm{aL}^{\mathrm{b}}
$$

where $\mathrm{W}=$ weight; $\mathrm{L}=$ length; $\mathrm{a}=$ regression intercept; $\mathrm{b}=$ slope. Therefore, by performing logarithmic transformations, the linear relationships could be represented by the equation $\mathrm{W}=0.00393 \mathrm{~L}^{3.305}\left(\mathrm{R}^{2}=0.939\right)$.

\section{Heavy Metal Concentrations in M. rosenbergii}

The concentrations of heavy metals in gill, exoskeleton and muscle of $M$. rosenbergii are given in Table 4.

The distribution of heavy metals in the body parts of $M$. rosenbergii, collected from the Sarawak River, followed this trend: $\mathrm{Zn}>\mathrm{Cu}>\mathrm{Co}>\mathrm{Cd}>\mathrm{Hg}$. In general, the concentration order of heavy metals in the body parts was found to be gills $>$ exoskeleton $>$ muscle. The results showed that there was no significant difference $(\mathrm{P}>0.05)$ between male and female $M$. rosenbergii. Overall, all the samples contained heavy metal concentrations below the permissible limits of Joint FAO/WHO Expert Committee on Food Additives (JECFA 2012) for human consumption $(\mathrm{Cd}<2 \mathrm{mg} / \mathrm{kg}$; $\mathrm{Cu}$ $<30.00 \mathrm{mg} / \mathrm{kg}$; Zn < $150 \mathrm{mg} / \mathrm{kg} ; \mathrm{Hg}<1 \mathrm{mg} / \mathrm{kg}$ ). Our heavy metal concentrations were also lower than the permitted values for $\mathrm{Cu}(<30 \mathrm{mg} / \mathrm{kg}), \mathrm{Zn}(<100 \mathrm{mg} / \mathrm{kg})$, and $\mathrm{Hg}(<1$ $\mathrm{mg} / \mathrm{kg}$ ) set by the Malaysian Food Regulations (1985), except low difference was recorded for $\mathrm{Cd}(<1 \mu \mathrm{g} / \mathrm{g})$. However, no safe limits were recorded for Co in both JECFA (2012) and Malaysian Food Regulations (1985), hence, no comparisons could be made in this study.

$\mathrm{Cd}, \mathrm{Co}, \mathrm{Cu}$, and $\mathrm{Zn}$ concentrations in gills were positively correlated $\left(r^{2}>0.500\right)$ to the total length of the prawns
(Fig. 2) and were significant $(\mathrm{P}<0.05)$. The positive relationship of heavy metal accumulation in organisms was often associated with their long time exposure to contaminants (Idrus et al. 2018, Elahi et al. 2012). Heavy metals can accumulate in prawn body parts which may transfer the chemical composition from one trophic level to another in the food chain, thus, giving human health a negative effect. Heavy metals were usually taken from the environment such as sediment by the prawns, then, distributed by circulation and subsequently accumulated in target organs, for example, gills.

In this study, the highest concentrations of all heavy metals were found in the gills. Gills are metabolically active body parts in the prawn and have a high tendency to accumulate heavy metals. This is due to the position and function of gills in which located as the starting points of heavy metals absorption and their function as the excretion site of contaminants from the body (Stanek et al. 2014). Moreover, gills are the primary target when crustaceans are exposed to waterborne pollutants, as gills are the major route for metal uptake (Seogianto et al. 2013, Fonseca et al. 2016). The concentration of $\mathrm{Cd}$ in $M$. rosenbergii in this study $(1.51 \pm 0.06 \mathrm{mg} / \mathrm{kg})$ was lower than Penaeus semisulcatus from Jazan $(6.33 \pm 2.08 \mathrm{mg} / \mathrm{kg}$ ) (Gendy et al. 2015), with the main source of $\mathrm{Cd}$ at their study sites was from the agricultural activities. However, their concentrations for $\mathrm{Zn}(24.00 \pm 7.80 \mathrm{mg} / \mathrm{kg}), \mathrm{Cu}(3.00 \pm 1.00 \mathrm{mg} / \mathrm{kg})$, and Co $(0.33 \pm 0.10 \mathrm{mg} / \mathrm{kg})$ in the prawns' gills were lower than our study. In comparison with the range concentrations of $\mathrm{Cu}(140.6-423.1 \mathrm{mg} / \mathrm{kg}), \mathrm{Cd}(18.10-38.07 \mathrm{mg} / \mathrm{kg})$ and Zn $(125.5953 .4 \mathrm{mg} / \mathrm{kg})$ in Penaeus semiculatus gills from

Table 4: Average concentrations of heavy metals ( $\mathrm{mg} / \mathrm{kg}$ wet wt) in different body parts of $M$. rosenbergii collected from the Sarawak River, and the safety limits (mg/kg wet wt)

\begin{tabular}{|c|c|c|c|c|c|}
\hline \multirow[t]{2}{*}{ Heavy metals } & \multirow[t]{2}{*}{ Body Parts } & \multicolumn{2}{|c|}{ Concentrations in average } & \multirow[t]{2}{*}{ JECFA (2012) limit } & \multirow[t]{2}{*}{ MFR (1985) limit } \\
\hline & & Male & Female & & \\
\hline $\mathrm{Cd}$ & $\begin{array}{l}\text { Muscle } \\
\text { Exoskeleton } \\
\text { Gill }\end{array}$ & $\begin{array}{l}0.46 \pm 0.08 \\
0.79 \pm 0.60 \\
1.53 \pm 0.06\end{array}$ & $\begin{array}{l}0.50 \pm 0.05 \\
0.57 \pm 0.23 \\
1.51 \pm 0.06\end{array}$ & 2.00 & 1.00 \\
\hline $\mathrm{Co}$ & $\begin{array}{l}\text { Muscle } \\
\text { Exoskeleton } \\
\text { Gill }\end{array}$ & $\begin{array}{l}\text { n.a. } \\
5.67 \pm 2.33 \\
15.17 \pm 0.83\end{array}$ & $\begin{array}{l}\text { n.a. } \\
3.99 \pm 1.01 \\
13.77 \pm 1.23\end{array}$ & NS & NS \\
\hline $\mathrm{Cu}$ & $\begin{array}{l}\text { Muscle } \\
\text { Exoskeleton } \\
\text { Gill }\end{array}$ & $\begin{array}{l}10.18 \pm 3.82 \\
10.47 \pm 5.30 \\
21.58 \pm 4.58\end{array}$ & $\begin{array}{l}6.62 \pm 2.28 \\
7.65 \pm 3.04 \\
17.09 \pm 1.91\end{array}$ & 30.00 & 30.00 \\
\hline $\mathrm{Zn}$ & $\begin{array}{l}\text { Muscle } \\
\text { Exoskeleton } \\
\text { Gill }\end{array}$ & $\begin{array}{l}13.76 \pm 2.24 \\
6.98 \pm 3.02 \\
59.17 \pm 12.13\end{array}$ & $\begin{array}{l}10.87 \pm 1.13 \\
7.36 \pm 0.64 \\
52.56 \pm 7.44\end{array}$ & 150.00 & 100.00 \\
\hline $\mathrm{Hg}$ & $\begin{array}{l}\text { Muscle } \\
\text { Exoskeleton } \\
\text { Gill }\end{array}$ & $\begin{array}{l}\text { n.a. } \\
\text { n.a. } \\
0.13 \pm 0.02\end{array}$ & $\begin{array}{l}\text { n.a. } \\
\text { n.a. } \\
0.11 \pm 0.03\end{array}$ & 1.00 & 1.00 \\
\hline
\end{tabular}

n.a. is not available, due to the concentrations were below the detection limit of the particular metals; NS, not specified; JECFA: Joint FAO/WHO Expert Committee on Food Additives; MFR: Malaysian Food Regulations 


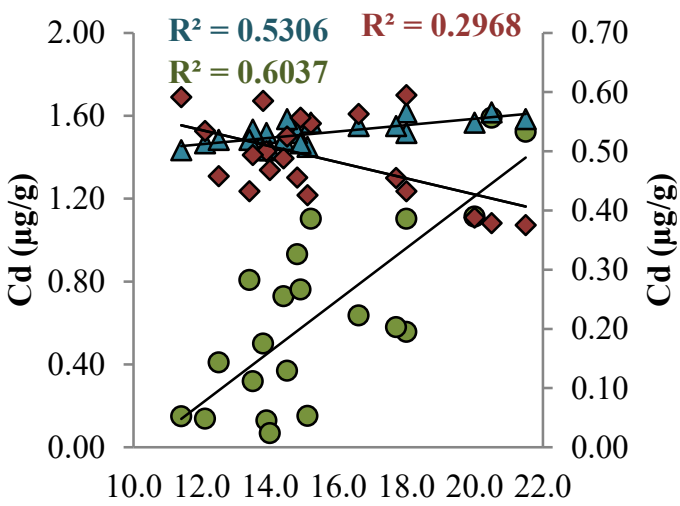

Total length (cm)

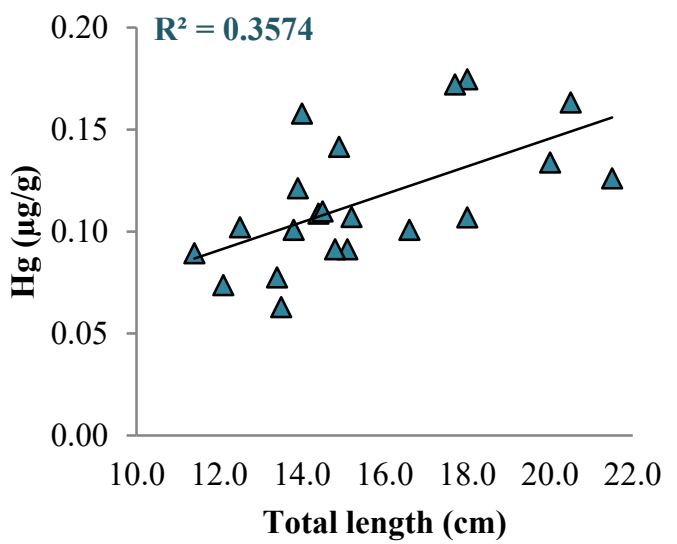

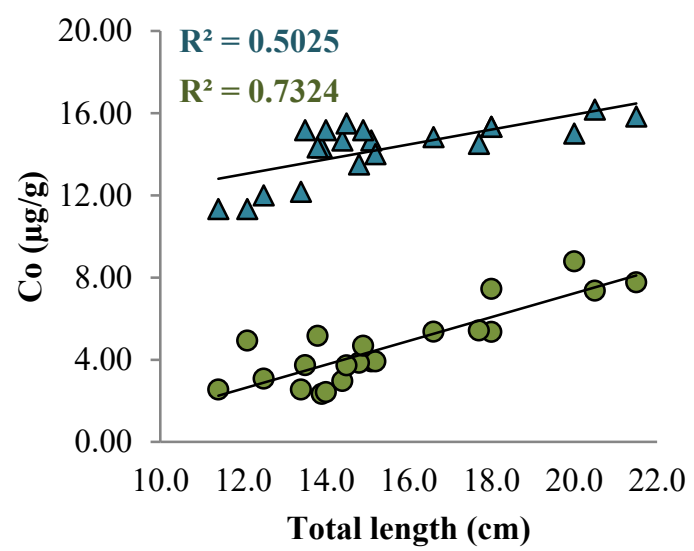

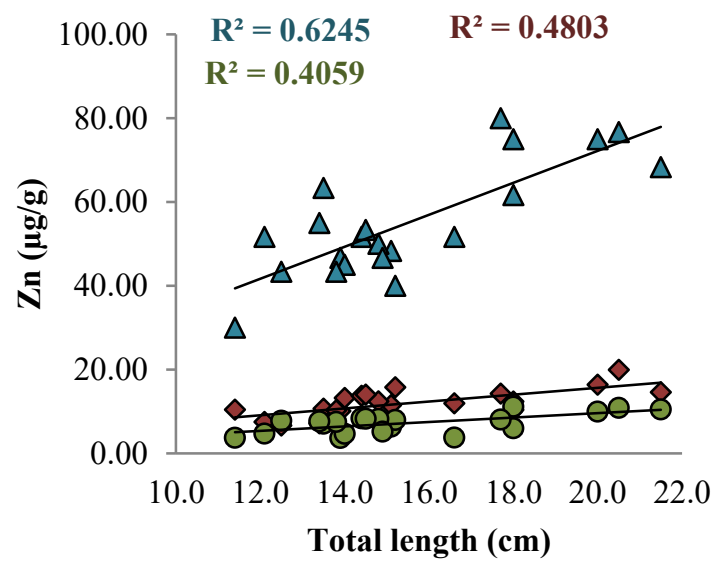

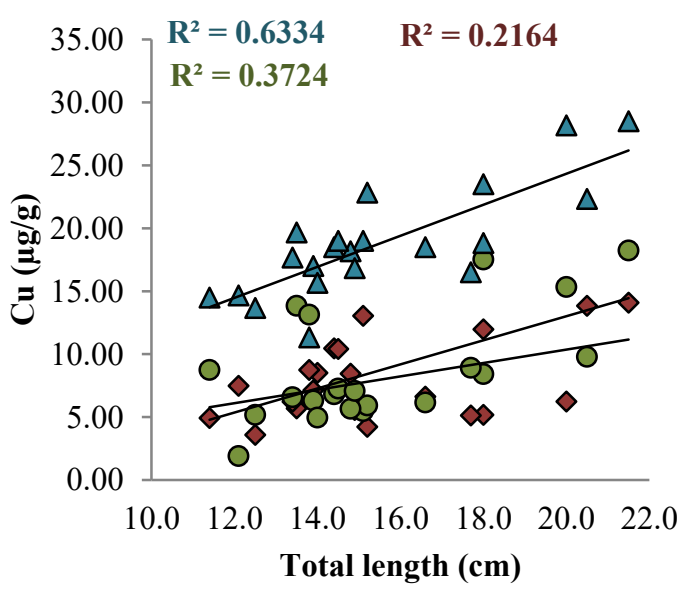

Fig. 2: Relationship between $\mathrm{Cd}, \mathrm{Co}, \mathrm{Cu}, \mathrm{Zn}, \mathrm{Hg}$ concentrations $(\mathrm{mg} / \mathrm{kg}$ ) and the total length $(\mathrm{cm})$ of $M$. rosenbergii in muscle (red diamond), exoskeleton (green circle) and gills (blue triangle) from Sarawak River.

Yumurtalik, Turkey,our values $(\mathrm{Cu}: 21.58 \pm 4.58 \mathrm{mg} / \mathrm{kg}$; Cd: $1.53 \pm 0.06 \mathrm{mg} / \mathrm{kg}$; Zn: $59.17 \pm 12.13 \mathrm{mg} / \mathrm{kg}$ ) were very much lower than them. Meanwhile, Mostafiz et al. (2020) obtained very high concentrations of $\mathrm{Cu}(83.94 \pm 18.32 \mathrm{mg} /$ $\mathrm{kg})$ and $\mathrm{Zn}(211.57 \pm 42.09 \mathrm{mg} / \mathrm{kg})$ in cephalothorax area (including gills) of wild $M$. rosenbergii in selected rivers of Chittagong and Chandpur, Bangladesh, as compared to this study, due to polluted rivers with heavy metals. 
$\mathrm{Cu}$ and $\mathrm{Zn}$ were also recorded higher in exoskeleton and muscle, with slightly positive $(\mathrm{P}<0.05)$ relationship (Fig. 2) shown in comparison with their total length. $\mathrm{Zn}$ is an essential metal for prawn and important in immune function, reproduction and body growth. $\mathrm{Zn}$ can reduce the adverse effect of phytic acid on the growth of prawns (Litopena vannamei) and also can increase the availability of macro minerals and micro minerals in the prawns (Bharadwaj et al. 2017). Zn also acts as a co-factor in many enzyme systems and essential component for metalloenzymes. It also involves in the signaling of molecules, DNA replication and repairing of the prawn cells, hence, increasing the survival rate of $M$. rosenbergii (Thirunavukkarasu et al. 2019). The increase of $\mathrm{Zn}$ concentration in the muscle occurred simultaneously by low concentration in the exoskeleton, suggesting a dynamical exchange of $\mathrm{Zn}$ between these two body parts. However, $\mathrm{Cu}$ concentrations were about the same in the exoskeleton and the muscle because $\mathrm{Cu}$ is known as one of the important components in the respiratory pigment haemocyanin and $\mathrm{Cu}$ is needed to trigger the enzymes and respiratory proteins. $\mathrm{Cu}$ and $\mathrm{Zn}$ in the prawn diet is a crucial route of accumulation in their body, particularly the muscles. High accumulation of $\mathrm{Cu}$ and $\mathrm{Zn}$ in muscles and exoskeleton can increase over time. Moreover, $M$. rosenbergii spends much of their time partially buried in the soft sediment and this may be the reason for the high $\mathrm{Cu}$ and $\mathrm{Zn}$ accumulation in prawns. It was in agreement with relatively high concentrations of $\mathrm{Zn}(84.54 \pm 10.22 \mathrm{mg} /$ $\mathrm{kg})$ and $\mathrm{Cu}(22.47 \pm 3.90 \mathrm{mg} / \mathrm{kg})$ in the sediment samples from the Sarawak River (Table 5). Our $\mathrm{Cu}$ concentrations in the $M$. rosenbergii muscles were nearly in the same range (19.35-34.23 mg/kg) for P. semiculatus muscles (Aytekan et al. 2019). However, their values (37.43-61.42 mg/kg) for $\mathrm{Zn}$ in the prawn muscles were higher than ours (10.87-13.76 $\mathrm{mg} / \mathrm{kg}$ ) (Aytekan et al. 2019). Our $\mathrm{Zn}$ and $\mathrm{Cu}$ values in the muscles were lower than the values obtained by Mostafiz et al. (2020) in their wild and farmed M. rosenbergii. Tu et al. (2008) also found higher concentrations of $\mathrm{Cu}$ and $\mathrm{Zn}$ in their $M$. rosenbergii muscles and exoskeletons.

$\mathrm{Cd}$ was recorded in the exoskeleton and muscle of our prawn samples. Statistically, the Cd concentrations in muscle and exoskeleton did not show a significance difference $(\mathrm{P}>$ 0.05). However, the relationship between total length and $\mathrm{Cd}$ concentration was slightly negative $\left(r^{2}=0.2968\right)$ in muscles. There was no clear reason that the smaller size of prawns has accumulated more $\mathrm{Cd}$ in their muscles, while sediment samples did not contaminate with $\mathrm{Cd}(1.17 \pm 0.02 \mathrm{mg} / \mathrm{kg}$,
Table 5). Cd concentrations in muscles and exoskeletons in this study were higher than the values obtained by Tu et al. (2008). On the other hand, our values were lower than $\mathrm{Cd}$ values reported by Islam et al. (2017) in both muscles and exoskeletons of their $M$. rosenbergii samples from Bagerhat, Bangladesh. In general, heavy metal content in exoskeletons and muscles may be reduced in the process of moulting where it involves the shedding of the hard chitinous exoskeleton layer, replaced by a new layer during the active grow (Stanek et al. 2014) and increasing new muscles. Therefore, the accumulation pattern of heavy metals in the exoskeleton and muscle of $M$. rosenbergii is hard to understand. Several factors such as diet, changes in metabolic rate, the hormonal and reproductive status may also influence metal accumulations in different sex of crustaceans (Idrus et al. 2018, Elahi et al. 2012).

The $\mathrm{Hg}$ concentration was not available for muscle and exoskeleton because it was below the detection limit of the FIMS. The gill was the only body part that contained a detectable concentration of $\mathrm{Hg}$ which was $0.125 \pm 0.024 \mathrm{mg} /$ $\mathrm{kg}$ in male and significantly higher $(\mathrm{P}<0.05)$ than in female $(0.107 \pm 0.033 \mathrm{mg} / \mathrm{kg})$. This lower $\mathrm{Hg}$ level may be due to their developed ability to excrete toxic elements from their body (Pourang et al. 2004). As the bioaccumulation process takes place through the absorption of metals via various routes including dietary and ambient environment (Arnot \& Gobas 2006), metal contents in the body of $M$. rosenbergii might be higher than in the surrounding environment.

\section{Bioaccumulation Factor}

Bioaccumulation factor (BAF) was calculated to assess the evolution of metals in different body parts of prawn samples collected from Sarawak River. BAF is the ratio of the concentration of contaminants in relation to its habitat environment (sediments). In this study, BAF was calculated as the ratio of metal concentrations in prawn and sediment samples using Equation 5 (Santoro et al. 2009).

$$
\mathrm{BAF}=\mathrm{M}_{\text {Body part }} / \mathrm{M}_{\text {sediment }}
$$

where $\mathrm{M}_{\text {Body part }}$ is metal concentration in $M$. rosenbergii body parts, $\mathrm{M}_{\text {sediment }}$ is metal concentrations in sediment.

If the BAF value was below 1, it may indicate that bioaccumulation was low and below the safety limit in our prawn samples, and if the BAF value was more than 1 , it is described as an increase of heavy metals level beyond the threshold (Anani \& Olomukora 2019). The BAF values for

Table 5: The concentrations $(\mathrm{mg} / \mathrm{kg}$ ) of heavy metals in the sediment of the Sarawak River.

\begin{tabular}{|c|c|c|c|c|c|}
\hline & $\mathrm{Cd}$ & Co & $\mathrm{Cu}$ & $\mathrm{Zn}$ & $\mathrm{Hg}$ \\
\hline Sediment & $1.17 \pm 0.02$ & $6.89 \pm 0.93$ & $22.47 \pm 3.90$ & $84.54 \pm 10.22$ & $0.05 \pm 0.01$ \\
\hline
\end{tabular}


all body parts of $M$. rosenbergii are presented in Table 6 . Our results reveal that $\mathrm{Cd}, \mathrm{Co}$ and $\mathrm{Hg}$ are bioaccumulative in prawn (female and male) gills, as related to the sediment concentrations. These results indicate that $\mathrm{Cd}, \mathrm{Co}$ and $\mathrm{Hg}$ are more easily available than other metals. The bioavailability could be controlled by metals speciation, food chain, physicochemical factors, particulate matter, organic carbon content and cation exchange capacity (Monikh et al. 2015). In this study, it also showed higher BAF values of heavy metals occurred in the gills and due to this, organ is known as the target organ for detoxification and circulation of heavy metals. Since $\mathrm{Cu}$ and $\mathrm{Zn}$ are required by prawns for their biological processes, these metals were distributed in their whole body, thus, leaving only residue quantity in the target organ (gill) (Monikh et al. 2015). The present study also showed that BAF values were slightly higher in male prawns, due to their larger size compared to female prawns. In comparison with the previous study in Kerang River (Idrus et al. 2018), the BAF value of $\mathrm{Cu}$ in male prawns' muscle was lower than this study, but recorded higher $\mathrm{Cu} B \mathrm{BF}$ value in the exoskeleton. The BAF of Cd value from the present study was considerably higher than the value in $M$. rosenbergii from the Mekong River Delta (Tu et al. 2008). However, a relatively lower concentration of $\mathrm{Cd}$ was recorded in the exoskeleton of their younger prawns compared to adults can be related to the lower frequency of the moulting process (Kouba et al. 2010).

\section{Human Health Risk Assessment}

The DIM value was calculated considering the average metal content and daily intake of giant freshwater prawns eaten, either as a whole prawn or as ingredients in their meal. The DIM for the present study is given in Table 7. In this study, the DIM values for $\mathrm{Cu}(2.29 \mu \mathrm{g} / \mathrm{kg}$ body weight per day), $\mathrm{Zn}$ ( $9 \mu \mathrm{g} / \mathrm{kg}$ body weight per day), Cd $(0.32 \mu \mathrm{g} / \mathrm{kg}$ body weight per day), and $\mathrm{Hg}(0.015 \mu \mathrm{g} / \mathrm{kg}$ body weight per day) were less than the provisional maximum tolerable daily intake (PMTDI) values set by JECFA (2012) for Cu (500 $\mu \mathrm{g} / \mathrm{kg}$ body weight per day), Zn (1000 $\mu \mathrm{g} / \mathrm{kg}$ body weight per day), $\mathrm{Cd}(1 \mu \mathrm{g} / \mathrm{kg}$ body weight per day), and $\mathrm{Hg}(60 \mu \mathrm{g} / \mathrm{kg}$ body weight per day). According to this finding, therefore, it can be concluded that the local population was safe from the health risk from ingestion of these metals.

The food chain is the most important pathway of heavy metals to humans, which could lead to significant human health risk. Considering the health risk of metals through dietary oral intake of the M. rosenbergii in Sarawak River, it is, therefore, useful to estimate the exposure level to humans in every element to oral RfD. The HRI associated with the individual elements of $\mathrm{Cd}, \mathrm{Co}, \mathrm{Cu}, \mathrm{Zn}$ and $\mathrm{Hg}$ due to prawn consumption was calculated as given in Table 7 . The highest HRI value was recorded in $\mathrm{Cd}(0.39)$, and the lowest value from $\mathrm{Cu}(0.002)$ for adults' consumption. Crustaceans and shellfish are natural accumulators of $\mathrm{Cd}$, especially if they

Table 6: The BAF values of $\mathrm{Cd}, \mathrm{Co}, \mathrm{Cu}, \mathrm{Zn}$ and $\mathrm{Hg}$ in different body parts of $M$. rosenbergii in the Sarawak River, related to the sediment concentrations.

\begin{tabular}{|c|c|c|c|c|c|c|}
\hline Sex & Body part & $\mathrm{Cd}$ & Co & $\mathrm{Cu}$ & $\mathrm{Zn}$ & $\mathrm{Hg}$ \\
\hline \multirow[t]{3}{*}{ Female } & Muscle & $0.43 \pm 0.04$ & N.A & $0.30 \pm 0.10$ & $0.13 \pm 0.01$ & N.A \\
\hline & Exoskeleton & $0.49 \pm 0.20$ & $0.58 \pm 0.15$ & $0.34 \pm 0.14$ & $0.09 \pm 0.008$ & N.A \\
\hline & Gill & $1.29 \pm 0.05$ & $2.00 \pm 0.18$ & $0.76 \pm 0.09$ & $0.62 \pm 0.09$ & $2.20 \pm 0.60$ \\
\hline \multirow[t]{3}{*}{ Male } & Muscle & $0.39 \pm 0.07$ & N.A & $0.45 \pm 0.17$ & $0.16 \pm 0.03$ & N.A \\
\hline & Exoskeleton & $0.68 \pm 0.51$ & $0.82 \pm 0.34$ & $0.47 \pm 0.24$ & $0.08 \pm 0.04$ & N.A \\
\hline & Gill & $1.31 \pm 0.05$ & $2.20 \pm 0.12$ & $0.96 \pm 0.20$ & $0.70 \pm 0.14$ & $2.60 \pm 0.40$ \\
\hline
\end{tabular}

N.A is not applicable as no value was obtained in the respective body parts

Table 7: The calculated daily intake metal (DIM, $\mu \mathrm{g} / \mathrm{kg} /$ day), health risk index (HRI) and hazard index (HI) values for heavy metals from the Sarawak River, and the provisional maximum tolerable daily intake (PMTDI, $\mu \mathrm{g} / \mathrm{kg} / \mathrm{day}$ ).

\begin{tabular}{|c|c|c|c|c|c|c|c|c|c|}
\hline $\mathrm{K}_{\text {conversion factor }}$ & $\mathrm{D}_{\text {average prawn intake }}(\mathrm{g} /$ day $)$ & $\mathrm{B}_{\text {average body weight }}(\mathrm{kg})$ & Metals & $\begin{array}{l}\text { Cmetal } \\
(\mu \mathrm{g} / \mathrm{g})\end{array}$ & $\mathrm{Rf}_{\mathrm{D}}$ & DIM & PMTDI & HRI & $\mathrm{HI}$ \\
\hline \multirow[t]{5}{*}{0.1455} & 150 & 60 & $\mathrm{Cd}$ & 0.89 & 0.83 & 0.32 & 1 & 0.39 & 0.69 \\
\hline & & & Co & 11.83 & 30 & 4.30 & - & 0.14 & \\
\hline & & & $\mathrm{Cu}$ & 6.31 & 500 & 2.29 & 500 & 0.002 & \\
\hline & & & $\mathrm{Zn}$ & 24.76 & 1000 & 9.00 & 1000 & 0.009 & \\
\hline & & & $\mathrm{Hg}$ & 0.04 & 0.1 & 0.015 & 60 & 0.15 & \\
\hline
\end{tabular}

$\mathrm{K}_{\text {conversion factor }}$ is followed Islam et al. (2017), $\mathrm{D}_{\text {average prawn intake }}$ is average daily intake of M. rosenbergii of the local residents near Sarawak River; $\mathrm{B}_{\text {average body weight }}$ is average body weight of the local residents near Sarawak River; $\mathrm{C}_{\text {metal }}$ is average metal concentrations; $\mathrm{Rf}_{\mathrm{D}}(\mu \mathrm{g} / \mathrm{kg} / \mathrm{day})$ is oral reference dose established by USEPA (1994, 2001), PMTDI (JECFA 2012). 
are exposed to the polluted environment with those metals such as sediment. In this study, the concentration of $\mathrm{Cd}$ in the sediment was $1.17 \pm 0.02 \mathrm{mg} / \mathrm{kg}$. M. rosenbergii is an example of some freshwater decapods that are bottom feeders, thus, they are at risk to concentrate more heavy metals than surface feeder prawns (Anani \& Olomukoro 2019). Accumulation of $\mathrm{Cd}$ in the human body may cause Parkinson's and Wilson's diseases (Hossen et al. 2015). Children also are at risk to have lower IQ and experience interference in the nervous system as $\mathrm{Cd}$ tend to accumulate in the choroids plexus in brain tissues, where the blood-brain barrier was absent in the young age (Wang \& Du 2013). Besides, it has been observed that $\mathrm{Cd}$ can be stored for a long time in the kidney, which can lead to tubular necrosis (Rehman et al. 2018). The accumulated metals in the M. rosenbergii was measured as the HI, based on the HRI. If the HI value was more than 1 , it is considered hazardous to human health. In this study, the HI value was 0.69 , indicating that prawns from Sarawak River are still safe for human consumption and has lower health risk.

\section{CONCLUSION}

In conclusion, the concentrations of $\mathrm{Cu}, \mathrm{Zn}$ and $\mathrm{Hg}$ in $M$. rosenbergii from the Sarawak River were within the permissible limits of JECFA and Malaysian Food Regulation, except for $\mathrm{Cd}$, which was slightly higher than the recommended value by the Malaysian Food Regulation. There is a need to establish a safety limit for Co to ensure that a comparison can be made. The concentrations of $\mathrm{Cd}, \mathrm{Cu}, \mathrm{Co}$, $\mathrm{Zn}$ and $\mathrm{Hg}$ were significantly correlated to their total body length, therefore, it was expected that bigger prawns could possess a higher concentration of metals in their body parts. Health hazard risks for most of the heavy metals were low; therefore, $M$. rosenbergii from Sarawak River were safe to be consumed in a considerable amount regularly.

\section{ACKNOWLEDGEMENTS}

The authors would like to thank the provider of Grant RAGS/ STWN01(01)/1178/2014(01) and UNIMAS for their support of this work.

\section{REFERENCES}

Anani, O.A. and Olomukoro, J.O. 2018. Health risk from the consumption of freshwater prawn and crab exposed to heavy metals in a tropical river, Southern Nigeria. Journal of Heavy Metal Toxicity and Diseases 3:1-7. https://10.21767/2473-6457.10024.

Anani, O.A. and Olomukoro, J.O. 2019. Assessment of metal accumulation and bioaccumulation factor of some trace and heavy metals in freshwater prawn and crab. In: Genaro Diarte-Plata and Ruth EscamillaMontes (Eds.), Crustacea, IntechOpen. https://doi.org/10.5772/ intechopen.88103.
Aytekin, T., Kargın, D., Çogun, H.K., Temiz, O., Varkal, H.S. and Kargın, F. 2019. Accumulation and health risk assessment of heavy metals in tissues of the shrimp and fish species from the Yumurtalik coast of Iskenderun Gulf, Turkey. Heliyon, 5(8): e02131. https://doi. org/10.1016/j.heliyon.2019.e02131.

Banu, R. and Christianus, A. 2016. Giant freshwater prawn Macrobrachium rosenbergii farming: A review on its current status and prospective in Malaysia. J. Aquac. Res. Dev. 7: 2. https://doi:10.4172/21559546.1000423.

Bharadwaj, A.S., Patnaik, S., Browdy, C.L. and Lawrence, A.L. 2017. Availability of dietary zinc sources and effects on performance of pacific white shrimp Litopenaeus vannamei (Boone). International Journal of Recirculating Aquaculture, 13: 1-10. http://doi.org/10.21061/ ijra.v13i0.1514.

Cui, Y.J., Zhu, Y.G., Zhai, R.H., Chen, D.Y., Huang, Y.Z., Qui, Y. and Liang, J.Z. 2004. Transfer of metals from soil to vegetables in an area near a smelter in Nanning, China. Environ. Int., 30: 785-791. https:// doi.org/10.1016/j.envint.2004.01.003.

Elahi, M., Esmaili-Sari, A. and Bahramifar, N. 2012. Total mercury levels in selected tissues of some marine crustaceans from Persian Gulf, Iran: Variations related to length, weight and sex. Bull. Environ. Contam. Toxicol., 88: 60-64. https://doi:10.1007/s00128-011-0451-4.

Eriksson, E., Srigirisetty, S. and Eilersen, A.M. 2010. Organic matter and heavy metals in greywater sludge. Water Sa., 36: 139-142. http://dx.doi. org/10.4314/wsa.v36i1.50921.

Finley, B.L., Monnot, A.D., Gaffney, S.H. and Paustenbach, D.J. 2012. Dose response relationships for blood cobalt concentrations and health effects: A review of the literature and application of a biokinetic model. J. Toxicol. Environ. Health, Part B: Critical Reviews, 15: 493-523, https://doi:10.1080/10937404.2012.744287.

Fonseca, A.R., Fernandes, L.F.S., Monteiro, S.M., Fontainhas-Fernandes, A. and Pacheco, F.A.L. 2016. From catchment to fish: Impact of anthropogenic pressures on gill histopathology. Sci. Total Environ., 550: 972-986. https://doi.org/10.1016/j.scitotenv.2016.01.199.

Gendy, A.E., Farraj, S.A. and Hedeny, M.E. 2015. Heavy metal concentrations in tissues of the shrimp Penaeus semisulcatus (De Haan, 1844) from Jazan, Southern Red Sea Coast of Saudi Arabia. Pakistan J. Zool., 47(3): 671-677. http://zsp.com.pk/pdf47/671-677\%20 (10)\%20PJZ-2170-15\%2010-5-15\%20El\%20Gendy \%20et $\% 20 \mathrm{al} \% 20$ -revised\%20final.pdf

Hameed, A.S.S. and Bonami, J.R. 2012. White tail disease of freshwater prawn, Macrobrachium rosenbergii. Indian J. Virol., 23: 134-140. https://doi:10.1007/s13337-012-0087-y.

Hossen, M.F., Hamdan, S. and Rahman, M.R. 2015. Review on the risk assessment of heavy metals in Malaysian clams. Sci. World J., 2015: 1-7. http://dx.doi.org/10.1155/2015/905497.

Idrus, F.A., Basri, M.M., Rahim, K.A.A., Rahim, N.S.A. and Chong, M.D. 2018. Concentrations of cadmium, copper, and zinc in Macrobrachium rosenbergii (Giant Freshwater Prawn) from natural environment. Bull. Environ. Contam. Toxicol., 100: 350-355. https://doi.org/10.1007/ s00128-018-2270-3.

Islam, G.R., Habib, M.R., Waid, J.L., Rahman, M.S., Kabir, J., Akter, S. and Jolly, Y. 2017. Heavy metal contamination of freshwater prawn (Macrobrachium rosenbergii) and prawn feed in Bangladesh: A market-based study to highlight probable health risks. Chemosphere, 170: 282-289. https://doi.org/10.1016/j.chemosphere.2016.11.163.

JECFA 2012. Joint FAO/WHO food standards programme Codex committee on contaminants in food. Sixth Session, Maastricht.

Jewel, M.A.S., Haque, M.A., Amin, R., Hasan, J., Lubna Alam, Mondal, S. and Ahmed, S. 2020. Heavy metal contamination and human health risk associated with sediment of Ganges River (Northwestern Bangladesh). Nature Environment and Pollution Technology, 19(2): 783-790. https:// doi.org/10.46488/NEPT.2020.v19i02.035. 
Kouba, A., Buřič, M. and Kozák, P. 2010. Bioaccumulation and effects of heavy metals in crayfish: A review. Water Air Soil Pollut., 211: 5-16. https://doi.org/10.1007/s11270-009-0273-8.

Mah, D.Y.S., Hii, C.P., Putuhena, F.J. and Lai, S.H. 2011. River modelling to infer flood management framework. Water SA, 37: 121-126.

Malaysian Food Regulation 1985. Malaysian Law on Food and Drugs. Malaysian Law Publishers, Kuala Lumpur.

Monikh, F.A., Maryamabadi, A., Savari, A. and Ghanemi, K. 2015. Heavy metals' concentration in sediment, shrimp and two fish species from the northwest Persian Gulf. Toxicology and Industrial Health, 31(6): 554565. https://doi.org/10.1177\%2F0748233713475498.

Mostafiz, F., Islam, M.M., Saha, B., Hossain, M.K., Moniruzzaman, M. and Habibullah-Al-Mamun, M. 2020. Bioaccumulation of trace metals in freshwater prawn, Macrobrachium rosenbergii from farmed and wild sources and human health risk assessment in Bangladesh. Environmental Science and Pollution Research, 27: 16426-16438. https://doi. org/10.1007/s11356-020-08028-4.

Natural Resources and Environmental Board Sarawak 2017. Target of cleaner, 'healthier' Sarawak River by 2021. Available at: http://www.nreb.gov. $\mathrm{my} / \mathrm{modules} / \mathrm{web} /$ pages.php? $\mathrm{mod}=$ news\&sub=news_view\&nid=272.

Pourang, N., Dennis, J.H. and Ghourchian, H. 2004. Tissue distribution and redistribution of trace elements in shrimp species with the emphasis on the roles of metallothionein. Ecotoxicology, 13: 519-533. https://doi. org/10.1023/B:ECTX.0000037189.80775.9c.

Rehman, K., Fatima, F., Waheed, I. and Akash, M.S.H. 2018. Prevalence of exposure of heavy metals and their impact on health consequences. J. Cell Biochem., 119: 157-184. https://doi.org/10.1002/jcb.26234.

Rocha, S.S.D., Silva, R.L.S.D., Santos, J.D.L. and Oliveira, G.D. 2015. Length-weight relationship and condition factor of Macrobrachium amazonicum (Heller, 1862) (Decapoda, Palaemonidae) from a reservoir in Bahia, Brazil. Nauplius, 23: 146-158. http://dx.doi.org/10.1590/ S0104-64972015002308.

Saher, N.U. and Kanwal, N. 2019. Assessment of some heavy metal accumulation and nutritional quality of shellfish with reference to human health and cancer risk assessment: A seafood safety approach. Environmental Science and Pollution Research, 26: 5189-5201. https:// doi.org/10.1007/s11356-018-3764-6.

Santoro, A., Blo, G., Mastrolitti, S. and Fagioli, F. 2009. Bioaccumulation of heavy metals by aquatic macroinvertebrates along the Basento River in the South of Italy. Water Air Soil Pollut., 201: 19-31. https://doi. org/10.1007/s11270-008-9923-5.

Sarkar, T., Alam, M., Parvin, N., Fardous, Z., Chowdhury, A., Hossain, S., Haque, M. and Biswas, N. 2017. Assessment of heavy metals contamination and human health risk in shrimp collected from different farms and rivers at Khulna-Satkhira region, Bangladesh. Toxicology Reports. https://www.scipedia.com/public/Sarkar_et_ al_2016a.

Stalin, A., Suganthi, P., Mathivani, S., Broos, K.V., Gokula, V., Sadiq Bukhari, A., Syed Mohamed, H.E., Singal, R.K. and Venu-babu, P. 2019. Effect of cobalt-60 gamma radiation on reproductive disturbance in freshwater prawn Macrobrachium rosenbergii (De Man, 1879). Toxicology Report, 6: 1143-1147. https://doi.org/10.1016/j. toxrep.2019.10.021.

Stanek, M., Dabrowski, J., Dlugosz, J. and Janicki, B. 2014. Impact of the anthropogenisation on the metals bioaccumulation and distribution in the Spiny-Cheek Crayfish (Orconectes limosus Raf.) from Lake Gaplo, Poland. Int. J. Environ. Res., 8: 1315-1322.

Thirunavukkarasu, M., Periyakali, S.B., Subramanian, R. and Perumal, S. 2019. Influence of two different dietary zinc sources in freshwater prawn Macrobrachium rosenbergii post larvae. J. Ocean. Limnol., 37: 290-299. https://doi.org/10.1007/s00343-018-7253-z.

Tu, N.P.C., Ha, N.N., Ikemoto, T., Tuyen, B.C., Tanabe, S. and Takeuchi, I. 2008. Bioaccumulation and distribution of trace elements in tissues of giant river prawn Macrobrachium rosenbergii (Decapoda: Palaemonidae) from South Vietnam. Fish Sci., 74: 109-119. https:// doi.org/10.1111/j.1444-2906.2007.01474.x.

USEPA 1994. Integrated Risk Information System Toxicological Summary for Cadmium. Available at: https://cfpub.epa.gov/ncea/iris2/ chemicalLanding.cfm?substance_nmbr=141.

USEPA 2001. Integrated Risk Information System Methylmercury (MeHg). Available at: https://cfpub.epa.gov/ncea/iris/iris_documents/ documents/subst/0073.htm.

Wang, B. and Du, Y. 2013. Cadmium and its Neurotoxic Effects. Oxidative Medicine and Cellular Longevity, 2013: 1-13. http://dx.doi. org/10.1155/2013/898034.

Yunus, K., Zuraidah, M.A. and John, A. 2020. A review on the accumulation of heavy metals in coastal sediment of Peninsular Malaysia. Emerald Publishing Limited. 